\title{
Telaah Dampak Boikot Produk Amerika terhadap Perekonomian Nasional
}

\author{
Heri Sudarsono \\ Universitas Islam Indonesia \\ herisudarsono_master@yahoo.co.id
}

A boycott plan of American products should consider national economy. The American products have contributed to the increase of national economic growth, because human and natural resource managements of Indonesia have depended on the American products. The boycott action would decrease economic growth, because it would decrease demands and increase unemployment. Besides, the action, on one side, would not be effective since economic relation between Indonesia and United States has been legitimized by both regional and international trade organization. On the other side, the dependency of Indonesia on American products have been relatively high, as seen from the volume of non oil and gas export-import between the two countries. Government economic policy is affected by cooperation with other countries, and therefore, the boycott action would not affect the decrease of consumption of American products.

Keywords: boycott, economy, legitimacy, trade.

\section{Pendahuluan}

Serangan Israel terhadap Palestina di jalur Saza telah menewaskan lebih dari 1000 orang. Peristiwa ini menimbulkan tragedi kemanusiaan di awal tahun 2009. Amerika yang diharapkan membantu meredam konflik antara Israel denngan Palestina ternyata hak vetonya mendukung Isreal. Keputusan Amerika menveto keputusan anggota dewan keamanan PBB untuk memberi saksi kepada Israel menimbulkan protes keras umat Islam dunia dan di Indonesia.

Berbagai tindakan untuk mengecam tindakan Isreal dan Amerika dilakukan oleh masyarakat Islam di dunia. Salah satu bentuk tindakan protes yang dilakukan oleh sekelompok umat Islam adalah melakukan boikot terhadao produk Amerika. Boikot adalah tindakan untuk tidak menggunakan, membeli, atau berurusan dengan seseorang, organisasi atau suatu negara sebagai wujud protes atau sebagai suatu bentuk pemaksaan. Friedman (1985) mendefinisikan boikot sebagai berikut:

...An attempt by one or more parties to achieve certain objectives by urging individual consumers to refrain from making selected purchases in the marketplace

Boikot produk Amerika ini dilakukan dikarenakan adanya indikasi, bahwa sebagian pendapatan nasional Amerika digunakan untuk membantu Israel baik secara langsung maupun tidak langsung. Secara langsung berupa bantuan dana yang digunakan untuk membantu pembangunan infrastruktur dan pengembangan senjata guna mempertegas eksistensi Israel di tanah Palestina. Bantuan yang tidak diberikan langsung adalah dukungan Amerika terhadap kebijakan-kebijakan Is- 
UNISIA, Vol. XXXI No. 70 Desember 2008

rael terhadap Palestina. Oleh karenanya, boikot produk Amerika sebagai dukungan moral atas perjuangan rakyat Palestina sekaligus protes atas tindakan Amerika yang mendukung Israel menyerang Palestina.

Harapan dari boikot produk Amerika ini ini adalah menurunnya permintaan atas barang dan jasa produk Amerika di pasar lokal maupun internasional. Produk Amerika disini adalah semua produk yang menjadi sumber pendapatan perusahan dan atau pendapatan pemerintah Amerika. Amerika mendapatkan pendapaan dengan membangun perusahaa-perusahaan internasional (international coorporation) di negara-negara di dunia. Amerika juga pendapatkan penghasilan dari ekspor produk dan jasa ke keseluruh negara-negara dunia. Tingginya pendapatan Amerika akan mempengaruhi besar besarnya alokasi anggaran untuk angkatan perang dan untuk membantu Israel

Namun apakah semua produk Amerika efektif untuk di boikot? Apakah tidak ada kendala yang mengganggu upaya boikot ini? Apa dampak boikot produk Amerika ini terhadap perekonomian nasional dan apakah solusi alternatif untuk mengurangi konsumsi produk Amerika ini? Tulisan ini akan memaparkan secara singkat produk yang memenuhi kriteria yang efektif untuk diboikot, dampak boikot dan masalah yang menganggu efektifitas boikot dan solusi alternatif.

\section{Efektivitas Boikot Produk Amerika di Indonesia}

Produk Amerika yang ada di Indonesia dapat dibedakan berdasarkan kedudukan/ lokasi perusahaan yang memproduksi produk barang dan jasa, bahan baku yang digunakan untuk menghasilkan produk dan tenaga kerja yang digunakan perusahaan.
Berbedaan lain produk Amerika, seperti merk/brand, bidang industri, lama perijinan, besarnya royali dan lain sebagainya tidak dimasukkan sebagai kriteria produk yang masuk daftar boikot dalam tulisan ini.

\section{1) Produk Asli Amerika}

Produk Amerika yang diproduksi perusahaan Amerika yang berkedudukan di Amerika, mengunakan bahan baku dan tenaga kerja Amerika. Produk ini langsung di impor dari Amerika melalui distributor yang berkedudukan di Indonesia dan dijual di Indonesia. Jenis produk yang masuk kriteria ini adalah produk mesin-mesin pabrik, mobil, barang-barang elektronik dan sofware. Produk ini diimpor dari Amerika dikarenakan produk tersebut tidak bisa dibuat di Indonesia sebab untuk memproduksi harus memenuhi bahan dan tenaga kerja yang memiliki standar dan spesifikasi tertentu. Produk tersebut hanya bisa didatangkan dari Amerika dan tidak bisa didatangkan dari negara lain disebabkan karena negara lain tidak bisa memproduksi atau karena kualitas produk yang dihasilkan tidak sepadan dengan produk Amerika.

Di samping itu, produk ini didatangkan dari Amerika karena produk tersebut masuk dalam kriteria produk yang dibutuhkan untuk memenuhi alat produksi dalam negeri. Produk Amerika ini masuk di Indonesia juga karena kesempakatan antara Amerika dan Indonesia mengenai objek perdagangan antara kedua belah pihak. Produk yang masuk dalam kriteria ini misalnya mesinmesin pabrik dan mobil Amerika yang bermerk Ford, Chrysler, Hammer, Chevrolet, dan Puck.

Perusahan-perusahaan besar dan sebagin kecil masyarakat yang memiliki penghasilan tinggi mengunakan produk Amerika ini. Oleh karenanya, produk 
Telaah Dampak Boikot Produk Amerika...; Heri Sudarsono

Amerika yang masuk kriteria ini memiliki potensi untuk mudah di boikot oleh sebagian besar masyarakat Indonesia. Apalagi mesinmesin berat yang digunakan pabrik tidak harus diperbaharui untuk setiap tahunnya. Mobil-mobil mewah yang mengunakan standard sama dengan produk Amerika juga bisa diganti dengan mobil mewah dari perusahan Jepang atau Korea.

Boikot produk Amerika bagi negara adalah berkurangnya pajak impor dari mesinmesin berat dan barang mewah. Negara juga kehilangan pemasukan dari pajak barang mewah untuk setiap tahunnya. Namun, pemasukan pajak dari barang mewah akan di pertahankan bila mobil mewah produk Amerika diganti dengan mobil-mobil Mewah Jepang dan Korea. Dampak langsung boikot ini bagi perekonomian bagi sebagian besar masyarakat relatif tidak ada, sedangkan dampak tidak langsung tergatung effekifitas pengeluaran negara dalam mengalokasi pada sektor publik.

\section{2) Produk Amerika diproduksi di Indonesia}

Produk Amerika yang masuk kriteria ini adalah produk yang dihasilkan oleh perusahaan multinasional yang perusahaan induknya ada di Amerika (Colman dan Nixson:1994). Karakter utama perusahaan multinasional adalah lingkup kegiatan income-generating (perolehan pendapatan) perusahaan multinasional dilakukan melampaui batas-batas negara, perda-gangan perusahaan multinasional kebanyakan terjadi di dalam lingkup perusahaan itu sendiri walaupun antar negara, kontrol terhadap pemakainan teknologi dan modal sangat diutamakan mengingat kedua faktor tersebut merupakan keuntungan kompetitif, serta pengembangan sistem manajemen dan distribusi yang melintasi batas-batas negara, terutama sistem modal ventura, lisensi, dan franchise/waralaba (Hadiwinata, B., Sugeng: 2002). Amerika memperoleh pendapatan dari pajak perusahaan yang beroperasi di Indonesia melalui perusahaan induknya. Orientasi utama perusahaan ini masuk ke Indonesia karena potensi pasar Indonesia yang luas dan tenaga kerja yang murah.

Perusahan ini mengunakan brand, label dan merk dari perusahaan induknya. Sebagian bahan baku yang digunakan berasal dari Indonesia sedangkan tenaga kerja yang digunakan adalah tenaga ahli yang sebagai besar tenaga kerja asing dan jumlah tenaga kerja Indonesia lebih banyak dari pada tenaga kerja asing. Jenis dan spesifiksi produk ini membutuhkan bahan baku yang semua tidak bisa di peroleh dari Indonesia Perusahaan yang masuk kriteria ini misalnya produk elektronik, bahan kimia, obat-obatan serta produk kecantikan. Yang masuk perusahaan multinasional adalah Coca cola, Dell, Enron, Exxon, Google, General Electric, General Motor, IBM, KalbeFarma, Microsoft, Nescle, Nike, Nokia, Yahoo dan lain-lain.

Masyarakat Indonesia banyak menggunakan produk-produk yang bermerk Amerika ini. Produk ini termasuk produk yang kurang ada barang pengantinya sehingga produk ini menjadi pilihan utama bagi sebagian masyarakat Indonesia. Apalagi sejumlah produk yang sudah lama menjadi brand image masyarakat telah membangun jaringan dalam berbagai bentuk produk dengan merk yang berbeda. Adapun merk dari produk-produk ini adalah Aloiez, Pampers, Ferry, Downy, Ariel, Tide, Head andShiulder, Pantene, Camay, Zeset, Mack Factor, Carmen, Shower and Shower, Nectar, Avon, Revlon, Gardena

Produk dengan jenis ini banyak di gunakan oleh masyarakat Indonesia sehingga memboikot produk ini adalah 
UNISIA, Vol. XXXI No. 70 Desember 2008

pekerjaan yang tidak mudah. Beralih pada produk lain tanpa ada alasan yang berhubungan dengan dirugikannya kepentingan masayarakt secara langsung akan sulit dilakukan. Apalagi dorongan boikot ini tanpa ada upaya sebelumnya untuk memberikan alternatif bagi masyarakat untuk beralih produk yang lain kualitas dan harganya kompetitif

Untuk produk yang masuk kriteria kedua di atas bisa dimasukkan dalam kriteria produk yang di boikor dengan sejumlah resiko. Pemboikotan produk ini akan menambah permintaan pada produk non Amerika yang jenisnya sama, namun dampaknya adalah kenaikan harga pada produk non Amerika karena meningkatnya permintaan atas produk non Amerika. Dampak lain dari boikot ini adalah meningkatnya pengangguran pada sektor industri, dan tindakan boikot produk yang bermerk Amerika ini juga akan mengurangi pendapatan negara dari pajak.

\section{3) Produk Amerika diproduksi Home Industry}

Produk Amerika yang diproduksi di Indonesia melalui waralaba (franchise) perusahaan Amerika atau perusahana induk yang berkedudukan di Amerika. Franchise didirikan dengan modal orang Indonesia yang mendapat lisensi untuk mendirikan usaha yang sama dengan perusahaan Amerika. Terwaralaba, perusahaan yang di Indonesia berhak mengunakan merek dagang, sistem manajemen, keuangan dan pemasaran. Frenchise Indonesia dapat membuka cabang di seluruh daerah di Indonesia dengan syarat yang telah di tentukan antara franchise dan pemerintah (PP.Menperindag No.12/2006).

Franchise berhak atas laba dari usaha yang dijalankanya, bertanggung jawab atas beban-beban usaha waralabanya sendiri, seperti pajak dan gaji pegawai. Diluar itu, franchise terikat pada aturan dan perjanjian dengan perusahaan induk Amerika sesuai dengan kontrak yang disepakti bersama. Oleh karena pajak dan gaji pegawai menjadi urusan franchise Indonesia maka tindakan boikot kepada produk ini akan menurunkan produksi perusahaan dampaknya pemasukan pajak negara menurun dan jumlah biaya produksi semakin besar. Bila biaya produksi selalu meningkat maka biaya tetap produksi akan di turunkan, dampaknya perusahaan akan memutuskan PHK pada sejumlah tenaga kerja

Produk yang masuk dalam kriteria ini adalah produk yang sudah dikenal oleh sebagian besar golongan masyarakat karena produk ini mudah ditemukan dan digunakn. Produk ini berjenis makanan, minuman, pakaian, sepatu, Popularitas produk ini di kalangan masyarakat karena dukungan modal yang besar dan manajemen modern. Yang masuk kriteria produk ini adalah produk makanan, minuman, sepatu dan baju dengan bermerk KFC, Arbys, McDonald, McBurger, Texas, A\&W, Pepsi, Coca-Cola. Nike, Adidas, Kate dan Calvin Klein.

Tindakan boikot terhadap produk ini tidak hanya mempengaruhi turunnya perekonomian Amerika, namun dampak terhadap turunnya perekonomian nasional. Hal ini disebabkan kandungan bahan baku yang digunakan untuk memproduksi produk ini dari dalam negeri, seperti daging ayam, sayur dan lain sebagiannya. Penghasilan peternak dan petani akan turun karena dampak langsung dari boikot produk ini. Selain itu tenaga kerja yang digunakan untuk mengelola operasi perusahaan untuk menghasilkan produk ini mayoritas berasal dari dalam negeri. Resiko ekonomi yang ditimbulkan dari boikot ini dari sisi pemerintah berkurangnya pendapatan 
Telaah Dampak Boikot Produk Amerika...; Heri Sudarsono

pemerintah dari pajak perusahaan dan meningkatnya krisis ekonomi dan sosial disebabkan bertambahnya pengangguran. makanan kesehatan dan obat-obatan Aloiez, Pampers, Ferry, Downy, Ariel, Tide, Head and Shiulder, Pantene, Camay, Zeset,

Tabel.1

Kriteria Produk Amerika yang ada di Indonesia

\begin{tabular}{|l|l|l|l|l|l|}
\hline \multicolumn{1}{|c|}{ Kriteria } & \multicolumn{1}{|c|}{$\begin{array}{c}\text { Kedudukan } \\
\text { Perusahaan }\end{array}$} & \multicolumn{1}{c|}{ Bahan Baku } & \multicolumn{1}{c|}{ Tenaga Kerja } & Jenis Produk & Merk atau Label \\
\hline $\begin{array}{l}\text { Produk Amerika } \\
\text { diproduksi di } \\
\text { Amerika }\end{array}$ & $\begin{array}{l}\text { Kedudukan } \\
\text { perusahaan yang } \\
\text { memproduksi barang } \\
\text { dan jasa ada di } \\
\text { teritorial Amerika. }\end{array}$ & $\begin{array}{l}\text { Bahan baku yang } \\
\text { digunakan dalam } \\
\text { produksi berasal dari } \\
\text { Amerika atau bahan } \\
\text { baku impor yang diolah } \\
\text { menjadi bahan baku } \\
\text { produksi }\end{array}$ & $\begin{array}{l}\text { Tenaga kerja yang } \\
\text { digunakan di perusahaan } \\
\text { untuk mengolah bahan } \\
\text { baku adalah berasal dari } \\
\text { Amerika }\end{array}$ & $\begin{array}{l}\text { Mesin pabrik, } \\
\text { Mobil, Laptop, } \\
\text { Softfare }\end{array}$ & $\begin{array}{l}\text { Ford, Crysler, Hammer, } \\
\text { Chevrolet, Puck }\end{array}$ \\
\hline $\begin{array}{l}\text { Produk Amerika } \\
\text { diproduksi di } \\
\text { Indonesia }\end{array}$ & $\begin{array}{l}\text { Kedudukan } \\
\text { perusahaan dalam } \\
\text { memproduksi barang } \\
\text { dan jasa dalam } \\
\text { teritorial Indonesia }\end{array}$ & $\begin{array}{l}\text { Bahan baku yang } \\
\text { digunakan dalam } \\
\text { produksi sebagian } \\
\text { berasal dari Amerika } \\
\text { yang tidak diperoleh di } \\
\text { Indonesia }\end{array}$ & $\begin{array}{l}\text { Kebanyakan tenaga ahli } \\
\text { yang digunakan dalam } \\
\text { produksi adalah berasal } \\
\text { dari Amerika, sedangkan } \\
\text { tenaga kerja produksi } \\
\text { kebanyakan dari } \\
\text { Indonesia. }\end{array}$ & $\begin{array}{l}\text { Alat-alat } \\
\text { kecantikan, } \\
\text { makanan kesehatan } \\
\text { dan obat-obatan }\end{array}$ & $\begin{array}{l}\text { Aloiez, Pampers, Ferry, Downy, } \\
\text { Pantene, Camay, Zeset, Mack } \\
\text { Factor, Carmen, Shower and } \\
\text { sower, Nectar, Avon, Revlon, } \\
\text { Gardena }\end{array}$ \\
\hline $\begin{array}{l}\text { Produk Amerika } \\
\text { diproduksi di } \\
\text { home industry }\end{array}$ & $\begin{array}{l}\text { Produk di buat dalam } \\
\text { teriorial Indonesia } \\
\text { yang mempunyai } \\
\text { potensi khusus }\end{array}$ & $\begin{array}{l}\text { Bahan baku yang } \\
\text { digunakan kebanyakan } \\
\text { berasal dari Indonesia }\end{array}$ & $\begin{array}{l}\text { Tenaga kerja yang } \\
\text { digunakan tenaga kerja } \\
\text { Indonesia }\end{array}$ & $\begin{array}{l}\text { Makanan dan } \\
\text { minuman cepat saji }\end{array}$ & $\begin{array}{l}\text { KFC, Arbys, McDonalds, } \\
\text { McBurger, Pizza Hut, Chilies, } \\
\text { Hardees, Paridies, Pizza Little } \\
\text { Sitzer, Jack in the Box, A\&W, } \\
\text { Kantez, Baskin Robbins, Wimpy, } \\
\text { Dominos Pizza, Texas, Slizer }\end{array}$ \\
\hline
\end{tabular}

Produk Amerika diproduksi di Amerika Kedudukan perusahaan yang memproduksi barang dan jasa ada di teritorial Amerika. Bahan baku yang digunakan dalam produksi berasal dari Amerika atau bahan baku impor yang diolah menjadi bahan baku produksi Tenaga kerja yang digunakan di perusahaan untuk mengolah bahan baku adalah berasal dari Amerika Mesin pabrik, Mobil, Laptop, Softfare Ford, Crysler, Hammer, Chevrolet, Puck.

Produk Amerika diproduksi di Indonesia Kedudukan perusahaan dalam memproduksi barang dan jasa dalam teritorial Indonesia Bahan baku yang digunakan dalam produksi sebagian berasal dari Amerika yang tidak diperoleh di Indonesia

Kebanyakan tenaga ahli yang digunakan dalam produksi adalah berasal dari Amerika, sedangkan tenaga kerja produksi kebanyakan dari Indonesia. Alat-alat kecantikan,
Mack Factor, Carmen, Shower and sower, Nectar, Avon, Revlon, Gardena

Produk Amerika diproduksi di home industry Produk di buat dalam teriorial Indonesia yang mempunyai potensi khusus Bahan baku yang digunakan kebanyakan berasal dari Indonesia Tenaga kerja yang digunakan tenaga kerja Indonesia Makanan dan minuman cepat saji K F C, A r b y s, McDonalds, McBurger, Pizza Hut, Chilies, Hardees, Paridies, Pizza Little Sitzer, Jack in the Box, A\&W, Kantez, Baskin Robbins, Wimpy, Dominos Pizza, Texas, Slizer

\section{Kendala Boikot Produk Amerika}

Selain dampak yang dihasilkan dari boikot cenderung akan menganggu ekonomi nasional, tindakan boikot ini juga akan mengalami berbagai kendala yang bersifat 
internal ataupun eksternal. Kendala yang bersifat ekstern adalah kesepakatan Indonesia dengan dunia internasional dan tingginya ketergantungan nasional terhadap produk Amerika. Sedangkan kendala internal adalah lemah bargaining position pemerintah dengan hadapan Amerika, dan belum optimalnya pengelola sektor riil.

\section{Kesepakatan organisasi Perdagangan Internasional}

Indonesia termasuk salah satu anggota negara pendukung perdagangan bebas (free trade) ditingkat regional atau Internasional. Untuk tingkat regional Indonesia menjadi anggota AFTA, sedangkan untuk internasional Indonesia menjadi salah satu anggota world trade organization (WTO). Indonesia telah menyepakati untuk terlibat dalam pasar bebas dengan menandatanganinya beberapa item produk Indonesia yang dibebaskan cukai dan pajak ketika masuk ke negera lain, demikian juga pembebasan cukai dan pajak dari beberapa produk yang disepakati dari negara lain masuk ke Indonesia. Kesepakatan-kesepakatan dilakukan antara Indonesia dan negara kawasan dan dunia untuk mendukung tercapainya perdagangan yang lebih bebas dan perjanjian yang dinegosiaiskan akan membantu pemerintah menghindari terjadinya perang dagang yang sangat merugikan (Krugman, Paul R \& Obstfeld, Maurice:2000).

Tidak semua produk masuk kesepakatan perdagangan bebas tergantung inisiatif kedua negara atau beberapa negara. Biasanya mempertimbangkan dampak daya saing produk dalam negeri terhadap produk luar negeri di masing-masing negara. Perdagangan bebas menjadikan tarif atau pajak impor produk luar negeri masuk ke Indonesia dikurangi sehingga produk luar negeri yang masuk ke Indonesia akan lebih murah.
Produk luar negeri akan menjadi saingan bagi produk dalam negeri. Masih banyak produk dalam negeri yang kurang kompetitif dibanding produk luar negeri, dengan keadaan ini semua produk dalam negeri tidak bisa diliberalisasikan. Apalagi salah satu misi liberalisasi bagi masyarakat adalah untuk memicu efesiensi produksi dalam negeri.

Masyarakat akan lebih memilih produk luar negeri yang lebih bagus dan murah dibanding produk luar negeri. Jika masyarakat sulit beralih ke produk nasional boikot tidak akan berjalan jika tidak ada produk penganti produk Amerika tersebut. Apalagi kenyataannya sebagian produk dalam negeri kualitasnya lebih rendah dan harganya lebih mahal di banding produk luar negeri. Lebih dilematis lagi, bila pemerintah membuat keputusan sepihak dengan melakukan boikot, hal ini bisa dianggap mengabaikan kesepakatan perdagangan bebas dan menganggu hubungan Indonesia dengan negara-negara yang terhimpun dalam organisasi perdagangan Asia atau dunia (Hadi Susastra:2004).

\section{Tinggi ketergantungan pada produk Amerika}

Ketergantungan Indonesia pada produk Amerika cukup tinggi dibanding dengan negara lain. Tabel. 2 menunjukkan nilai ekspor dan impor non migas Indonesia ke Amerika dari tahun 2000 sampai 2007. Selain Jepang, Cina dan Singapura, Amerika merupakan negara yang nilai ekspor dan impor non migas tinggi. Jadi pemerintah mendapatkan pendapatan luar negeri sebagian besar dari penjualan produk dalam negeri ke Amerika, demikian juga kita mendatangkan bahan mentah/suku cadang sebagai faktor produksi dariAmerika. Oleh karenanya, ketergantungan ini ditunjukkan dengan besar pengaruh nilai dolar terhadap rupiah. 
Telaah Dampak Boikot Produk Amerika...; Heri Sudarsono

Tabel.2 Ekspor Non Migas Indonesia ke Berapa Negara Tujuan 2000-2008 (ribu USD)

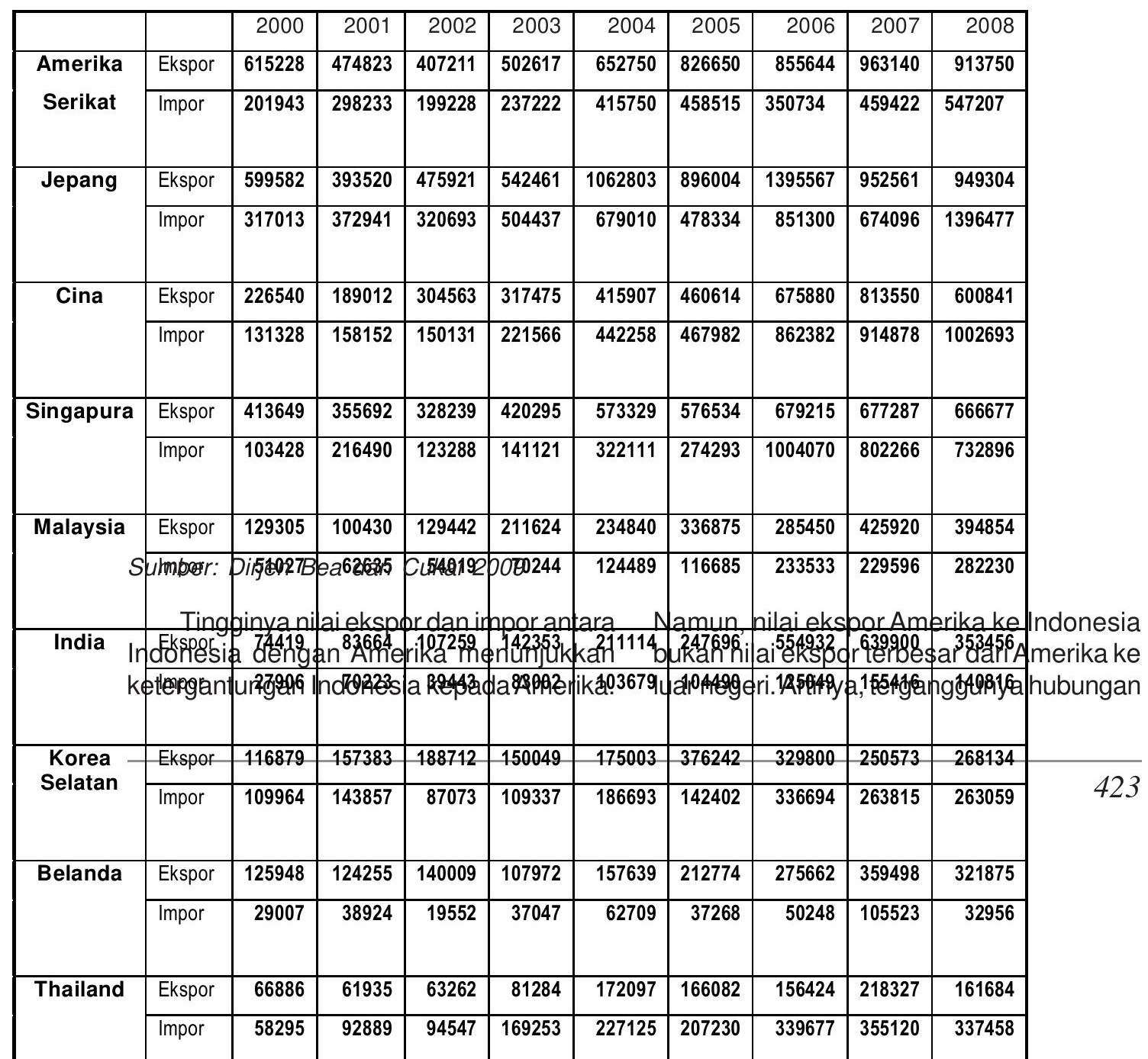


UNISIA, Vol. XXXI No. 70 Desember 2008

perdagangan bilateral antara Indonesia dengan Amerika akan lebih merugikan Indonesia. Hal ini akan menjadi kendala boikot produk Amerika. Selain itu, resiko balasan yang akan diberikan Amerika kepada Indonesia dengan mengurangi impor produk Indonesia dampaknya lebih serius dibanding dengan dampak ekonomi yang dihasilkan dari boikot produk Amerika.

\section{Campur tangan pemerintah}

Kesepakatan Indonesia dengan negaranegara di kawasan regional maupun internasional tentang perdagangan bebas menganggu sikap tegas pemerintah untuk memboikot produk Amerika. Tindakan boikot akan lebih memenuhi sasaran bila ada turut campur pemerintah sebagai pemegang kebijakan di bidang ekonomi. Namun, kesepakatan tentang perdagangan bebas menjadikan kebijakan-kebijakan pemerintah yang berhubungan dengan proteksi perdagangan luar negeri harus melalui dialog dengan berbagai pihak yang terlibat dalam perjanjian bersama melalui forum perdagangan bilateral atau internasional. Kebijakan pemerintah yang mendukung tindakan boikot secara sepihak akan menganggu kesempakatan ini. Indonesia akan mendapatkan balasan dari Amerika dan negara lain dengan menerapkan proteksi atas barang Indonesia yang masuk di negara mereka.

Kebijakan perdagangan Indonesia dengan luar negeri, baik bilateral atau multilateral, tidak mudah diputuskan secara sepihak tanpa melalui forum resmi yang mengundang negara-negara yang berkepentingan. Dalam membuat kebijakan di forum pun harus mempertimbangkan negara-negara yang berkepentingan supaya tidak merugikan salah satu pihak. Indikator ekonomi Indonesia yang relatif rendah menjadikan bargaining power pemerintah terhadap negara lain rendah. Hal ini menjadikan ketergantungan Indonesia terhadap negara lain cukup tinggi maka kebijakan pemerintah untuk memboikot produk luar negeri akan berdampak negatif bagi perekonomian dalam negeri. Apalagi dampak politik perdagangan yang akan mempengaruhi turunnya kredibilitas Indonesia di mata internasional terhadap komitmen perdagangan bebas yang menjadi kesepakatan bersama.

\section{Pasar dalam negeri masih membutuhkan produk Amerika}

Perusahaan multinasional yang perusahaan induknya di Amerika atau perusahaan Amerika yang membuka franchise di Indonesia seperti Mc Donald, Dunkin Donut, KFC sudah lama menjalankan operasinya di Indonesia. Perusahaan tersebut bukan hanya menguntungkan Amerika dikarenakan menerima pajak dari perusahaan induk yang mendapatkan pendapatan dari franchise yang ada di Indonesia. Namun, juga perusahaan-perusahaan franchise tersebut telah menghidupi ribuan peternak, petani dan pegawai di franchise yang berkedudukan hampir di seluruh kota-kota besar di Indonesia. Pada saat kemiskinan dan pengangguran meningkat di negara kita tindakan memboikot produk franchise semacam ini bukan hanya menimbulkan masalah ekonomi tetapi juga sosial dan politik.

Impor produk manufaktur yang kebanyakan didatangkan dari Amerika menunjukkan bahwa ketergantungan produk ini dari Amerika cukup tinggi. Produk-produk ini pergunakan untuk bahan baku produk yang digunakan untuk kebutuhan dalam ataupun luar negeri. Di lain pihak sejumlah produk yang didatangkan dari Amerika karena untuk 
Telaah Dampak Boikot Produk Amerika...; Heri Sudarsono

memenuhi kebutuhan konsumsi masyarakat Indonesia. Merk dan kualitas produk Amerika yang cukup dikenal Indonesia menjadi masyarakat tidak mudah meninggalkan produk Amerika yang telah dikonsumsi sejak lama.

\section{Kebijakan jangka pendek}

Tindakan boikot yang dilakukan oleh beberapa kalangan disebabkan agresi Israel terhadap Jalur Gaza, Palestina. Tindakan ini bentuk protes kepada Amerika yang yang membantu Israel dalam menyerang Palestina. Isu atau tindakan boikot tidak akan menjadi bahan protes kalau Israel tidak menyerang Palestina. Oleh karenanya, tindakan boikot lebih didasarkan atas alasan emosi karena tindakan Israel yang menyerang Gaza dan Amerika yang membantu Israel. Tindakan yang di dasarkan akan emosi akan cenderung menghasilkan kebijakan yang bias dan berlaku sesat karena sumber informasi kebijakan yang digunakan bersifat jangka pendek (Kjell Knudsen, Pravee Aggarwal, and Ahmed Maamoun:2008).

Perekonominan yang dibangun antara Indonesia dan Amerika yang dilakukan bertahun-tahun melalui pengambangan hubungan dan infrastruktur yang sudah baik. Pengembangan pasar yang dihasilkan dari perdagangan kedua belah pihak yang telah menghasilkan devisa yang besar dan berlaku bertahun-tahun akan sulit dihentikan dengan tindakan boikot yang dilakukan karena reaksi sesaat atas adanya suatu peristiwa yang mengugah sisi emosional manusia yang bersifat sementara.

Tindakan boikot yang kebanyakan di usung oleh sekelompok dan segolongan umat Islam menimbulkan bias atas kebijakan ini karena adanya tendensi perbedaan ideologi dalam tindakan boikot ini. Tindakan oleh sebagian kalangan ini menjadi representasi, bahwa boikot lebih disebabkan alasan emosi bukan ekonomi sehingga tindakan boikot yang diusulkan dianggap tidak menyentuh subtansi persoalan ekonomi masyarakat.

\section{Pembahasan}

Boikot produk Amerika bukan keputusan instan yang hanya bertujuan untuk melakukan protes Amerika. Boikot seperti ini tidak akan tepat sasaran karena tidak akan siqnifikan mempengaruhi konsumsi umat Islam terhadap produk Amerika. Oleh karena itu boikot lebih efektif dampaknya kalau agenda yang kita usung lebih berorientasi pada pengurangan ketergantungan pada produk Amerika. Dampak dari realisasi agenda ini menuntut perencanaan yang lebih terukur dan memerlukan waktu yang tidak pendek.

\section{Industri subtitusi impor (ISI) dengan mengembangkan industri kreatif}

Perencanaan untuk mengurangi konsumsi produk Amerika adalah dengan menghidupkan kembali ISI yang berorientasi pada produk-produk luar negeri guna mengurangi ketergantungan dari produkproduk impor. Produk ini digunakan untuk mengantikan produk luar negeri dengan produk dalam negeri dengan kriteria tenaga kerja dan bahan bakunya bisa diperoleh di Indonesia. Negara kita kaya dengan sumber daya alam (SDA) dan sumber daya manusia (SDM), ini merupakan potensi awal yang bisa digunakan untuk menghidupkan kembali ISI.

Strategi ini pernah dilakukan pada masa pemerintahan orde baru namun strategi ini mengalami kegagalan ketika masa 
UNISIA, Vol. XXXI No. 70 Desember 2008

liberalisasi. Namun strategi ini layak untuk diperhatikan untuk mengurangi ketergantungan terhadap produk luar negeri. Strategi ini mengandung dimensi tidak saja ekonomi tetapi politis perdagangan dengan mitra dagang. Dari sisi ekonomi, pemerintah mampu menambah lapangan kerja. Secara politis perdagangan, ketergantungan negara terhadap luar negeri akan menurun sehingga meningkat bargaining position Indonesia di mata Internasional.

Pengembangan ISI bisa melalui pemberdayaan industri-industri kreatif yang mengunakan potensi lokal sebagai bahan pengembangan sumberdaya manusia di perguruan tinggi belum mampu menyediakan SDM yang berorientasi pada memperdayakan industri kreatif.

Dalam hal ini pemerintah memiliki peran penting dalam membuat kebijakan yang mengakomodasi seluruh kegiatan ekonomi masyarakat, melalui SDM, modal, fasilitas dan regulasi pemerintah. Kebijakan-kebijkan tersebut diarahkan pada kemandirian ekonomi dengan mengoptimalkan potensi sumber daya hayati dan insani yang tidak bisa dipisahkan dari budaya-ekonomi masyarakat. Oleh karenanya, pengem-

\section{Gambar. 1 Faktor yang Mempengaruhi Sektor Riil/Industri Kreatif}

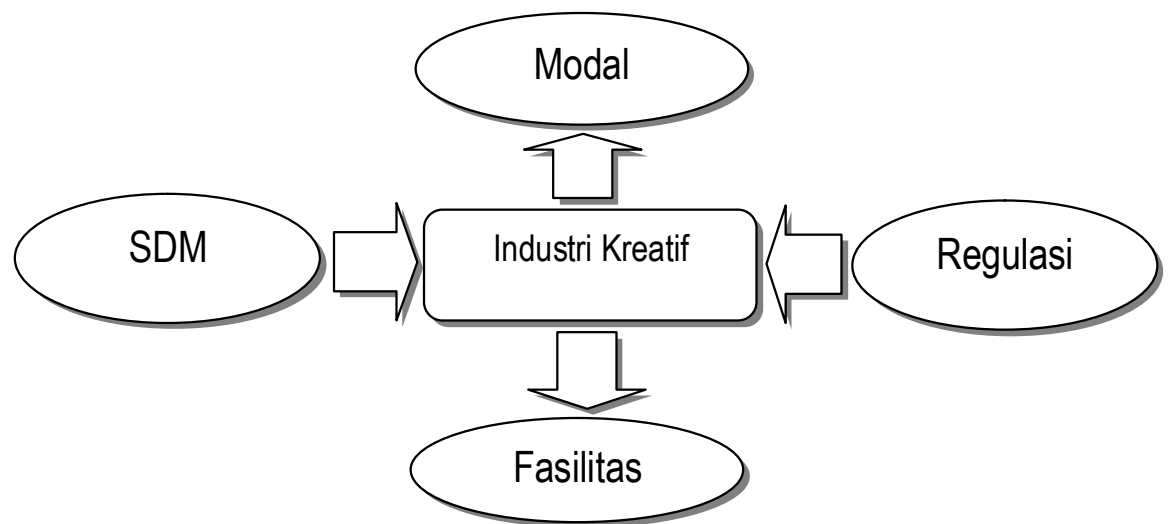

baku utama (Christiane Eisenberg, Rita Gerlach and Christian Handke (eds.): 2006). Namun, ada beberapa masalah dalam pengembangan industri kreatif di negara kita antara lain; industri kreatif relatif baru dan belum diakui sebagai penggerak roda pembangunan, tidak ada data nilai ekonomi dan perkembangan industri kreatif, belum tersedia kebijakan yang mendukung iklim kreatif: perijinan, investasi, dan perlindungan hak cipta, dan kegiatan kreatif masih terkotak-kotak dan belum ada kajian rantai nilai yang utuh mulai dari kegiatan kreasi, produksi, dan distribusi. Demikian juga, bangan ISI melalui pengembangan industri kreatif akan mengoptimalkan potensipotensi insani melalui pemgembangan potensi ekonomi daerah.

\section{Imitasi produk Amerika}

Strategi subtistusi impor ini juga bisa dilakukan dengan melakukan imitasi produk Amerika. Di berbagai daerah muncul produkproduk yang meniru karakter produk Amerika; dari nama, bentuk, kemasan, rasa dan pelayanan. Produk tiruan ini berbeda karena nama, kemasan, harga, kemasan, rasa dan pelayanan berbeda dengan produk- 
Telaah Dampak Boikot Produk Amerika...; Heri Sudarsono

produk Amerika. Oleh karenannya strategi imitasi produk Amerika seperti ini tidak menyalahi hak paten karena nama, kemasan, harga, kemasan yang digunakan relatif tidak sama.

Produk lokal, seperti makanan, obatobatan dan elektronik, diorientasi untuk mengantikan produk Amerika dengan strategi imitasi akan banyak mengurangi mampu melakukan inovasi sesuai dengan pemenuhan kebutuhan dalam negeri.

Strategi imitasi memiliki tujuan untuk menghindari ketergantungan dari produk luar negeri dan meningkatkan produksi nasional. Pemenuhan target jangka panjang akan menurunkan konsumsi terhadap produk luar negeri dan meningkatkan konsumsi dalam dalam negeri. Bila konsumsi dalam negeri

Gambar. 2 Target dalam Imitasi Produk Amerika

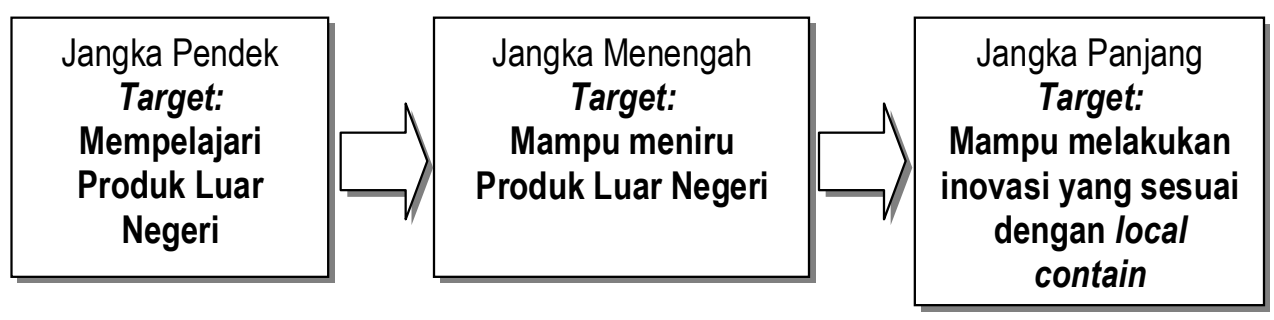

konsumsi masyarakat terhadap produk Amerika dan akan menambah pendapatan masyarakat yang bekerja di sektor rill yang mengunakan produk imitasi dari franchise perusahaan Amerika. Indonesia juga bisa mengembangkan produk imitasi tersebut sesuai dengan local contain, dimana bahan yang digunakan berasal dari dalam negeri. Strategi ini juga bisa memuat local wisdom, dimana produk bisa di inovasi dengan citra rasa Indonesia.

Konsep imitasi produkAmerika didasarkan pemenuhan target full national contain di masa depan. Oleh karenanya, implementasi untuk mengunakan produk sendiri melalui imitasi produk harus di rencanakan. Perencanaan produk ini memenuhi jangka pendek, menengah dan jangka panjang. Jangka pendek ditargetkan mempelajari produk Amerika atau negara lain, Jangka menengah mampu membuat produk yang memiliki kualitas yang sama dengan produk luar negeri dan; jangka panjang ditarget mampu dipenuhi oleh produksi alam negeri akan menimbulkan akselerasi positif terhadap peningkat pendapatan nasional

\section{Meningkatkan peran sektor keuangan dan koperasi}

Pemberdayaan sektor riil dalam upaya untuk mengurangi ketergantungan luar negeri tidak akan optimal kalau tidak ada dukungan dari lembaga keuangan, seperti bank, BPR, dan KSP. Peran lembaga keuangan sangat penting dalam rangka untuk menjaga kesinambungan usaha melalui ketersediaan dana yang dibutuhkan sektor riil, administrasi yang mudah, dan pelayanan yang cepat. Perkembangan sektor riil, terutama usaha mikro, kecil dan menengah (UMKM) sering terbentur pada nilai jaminan dan tingkat bunga yang tinggi.Sementara itu tidak semua bank membuka diri untuk memberikan pembiayaan bagi UMKM karena alasan menjaga keamanan likuiditas bank (Impres No. 6 tahun 2007). 
UNISIA, Vol. XXXI No. 70 Desember 2008

Problem utama UMKM adalah tidak memiliki jaminan yang nilainya memadai untuk mendapatkan dana optimal dalam mengelola usahanya di samping itu tingkat bunga yang tinggi sering menjadi problem keuangan pada UMKM. Sedangkan, problem lain yang bagi UMKM adalah pajak usaha yang tidak akomdatif terhadap nilai usaha, kurangnya ketersedian fasilitas publik yang diberikan pemerintah mendukung usaha, dan UMKM harus mampu bertahan di dalam persaiangan bebas tanpa ada perlindungan langsung dari bank atau pemerintah.

Untuk itu perlu peran koperasi dalam mengatasi persolan UMKM. Koperasi sebagai soko guru perekonomian guna mendukung terbangunnya sektor riil. Sektor riil tidak akan bisa hidup kalau tidak ada tungan produk dalam negeri. PT lebih condong mencetak pegawai-pegawai yang siap kerja di perusahaan swasta dan negeri. PT jarang mengarahkan anak didiknya menjadi entrepreneur yang mampu mengelola dan mengembangkan sektor ekonomi. Kenyataan ini bisa di lihat dari kompetensi kurikulum PT yang lebih mengedepankan anak didiknya untuk siap menjadi pekerja yang duduk belakang meja. Perubahan kurikulum yang sesuai dengan kompetensi akan menjadikan anak didik menjadi insan trampil yang siap mengelola industri-industri kreatif (SK Mendiknas No. 232/U/2000 dan 045/U/2002).

Perguruan tinggi bukan merupakan sekedar lembaga bisnis tetapi juga lembaga sosial yang harus mampu mengakomadasi

Gambar. 3

Muatan Kurikulum yang Berbasis pada Pengembangan

sistem pendukung yang mampu mengakomodasi ketersediaan bahan baku, proses pengolahan, distribusi output produksi. Koperasi mempunyai peran sebagai sistem pendukung yang memiliki peran sebagai koordinator dalam suatu pengelolaan sektor riil.

\section{Kompetensi institusi pendidikan}

Perguruan tinggi memiliki peran strategis dalam mempengaruhi ketergan- kepentingan sosial sehingga PT tidak terasing di tengah-tengah persoalan kehidupan. Kurikulum PT harus mampu menjawab persoalan-persoalan riil kemasyarakatan. Oleh karena itu, jalinan hubungan dunia pendidikan dan industri tidak bisa terputus, kalau tidak mau dikatakan perguruan tinggi tersebut putus dari realitas.

Peran PT dalam pengembangan industri kreatif dapat di fokuskan pada penyusunan kurikulum yang berbasis pada 
Telaah Dampak Boikot Produk Amerika...; Heri Sudarsono

pengembangan industri kreatif. Hal ini bisa dilakukan bila kurikulum PT memenuhi muatan dibidang agama/norma, teknologi, bahasa asing, dan muatan lokal. Kurikulum PT merupakan representasi dari kebutuhan industri kreatif yang bercirikan pada keunggulan kreatifitas yang ditopang oleh keunggulan kompetitif daerah/lokal

\section{Penutup}

Tindakan boikot terhadap produk Amerika hendaknya mempertimbangkan resiko ekonomi nasional. Produk Amerika memiliki kontribusi bagi peningkatan pertumbuhan ekonomi dalam negeri, karena pengelolaan SDM dan SDA di Indonesia masih memiliki ketergantungan pada produksi produk Amerika. Tindakan boikot akan menurunkan pertumbuhan ekonomi karena menurunkan permintaan dan meningkat jumlah pengangguran

Disamping itu, tindakan bokot kurang efektif karena hubungan ekonomi Indonesia dan Amerika mendapat legitimasi oleh organisasi perdagangan regional dan internasional. Di lain pihak ketergantungan Indonesia pada produk Amerika cukup tinggi terbukti dengan besarnya nilai ekspor-impor non migas antara Indonesia dan Amerika. Kebijakan ekonomi pemerintah dipengaruhi oleh kerjasama dengan negara lain oleh karena itu tindakan boikot tidak akan banyak berpengaruh bagi berkurangnya konsumsi produk Amerika.

Langkah yang startegis agar pemerintah tidak tergantung lagi pada produk Amerika adalah menghidupkan kembali industri subtitusi impor, melalui pemberdayaan industri kreatif. Hal lain yang bisa dilakukan adalah secara bertahap melakukan imitasi dan inovasi atas produk Amerika. Peran lembaga keuangan dan koperasi memiliki posisi penting dalam meningkat gairah sektor industri penganti impor ini.

Dukungan Perguruan Tinggi sangat diperlukan dalam rangka menyediakan SDM yang dibutuhkan. Penyesuaian kurikulum yang bervisikan pada pengalian potensi bangsa melalui pengembangan industri kreatif sangat diharapkan. Oleh karenanya dalam menyusun kurikulum, PT harus mempertimbangkan agama, bahasan, teknologi dan muatan lokal.

\section{Daftar Pustaka}

Colman, D. and F. Nixson,1994. Economics of Change in Less Developed Countries, London: Harvester

Eisenberg, Christiane. Gerlach, Rita and Handke, Christian (eds.),2006. Cultural Industries: The British Experience in International Perspective, Berlin; Humboldt-Universitat Zu.

Friedman, Monroe,1985. "Consumer Boycotts in the United States, 1970-1980: Contemporary Events in Historical Perspective", Journal of Consumer Affairs, Vol. 19, pp. 96-117.

Knudsen, Kjell, Aggarwal, Praveen, and Maamoun, Ahmed,2008. "The Burden of Identity: Responding to Product Boycotts in the Middle East", Journal of Busiess \& Research, Vol. 6, No. 11 , pp. 8-9

Krugman, Paul R \& Obstfeld, Maurice, 2000. International Economics, Theory and Policy, Fitth Edition, NJ: AddisosnWesley Publising Company

Sugeng, B, Hadiwinata,2002. Politik Bisnis Internasional, Yogyakarta:Kanisius 
UNISIA, Vol. XXXI No. 70 Desember 2008

Susatra, Hadi ,2004. Kebijakan Persaingan, Throsby, David, 2001. Economics and CulDaya Saing, Liberalisasi, Globalisasi, ture. Cambridge; CUP. Reegionalisasi dan Semua itu, CSIS Working Paper Series, WPE 082. 